\title{
A MUTANT OF THE PHOTOTOXIC PROTEIN KILLERRED THAT DOES NOT FORM DSRED-LIKE CHROMOPHORE
}

\section{Gorbachev DA, Sarkisyan KS $\bowtie$}

Shemyakin-Ovchinnikov Institute of Bioorganic Chemistry, Moscow, Russia

Genetically encodable photosensitizers based on fluorescent proteins produce reactive oxygen species when illuminated with light. Although widely used as optogenetic tools, existing photosensitizers with green fluorescence possess suboptimal properties motivating for a search of new protein variants with efficient chromophore maturation and high phototoxicity. Here we report a mutant of the phototoxic fluorescent protein KillerRed protein with fluorescence in the green part of the spectrum. The mutant variant carries mutations I64L, D114G, and T115S and does not form a DsRed-like chromophore. The protein can be used as a template to create new genetically encodable photosensitizers that are spectrally different from KillerRed.

Keywords: photosensitizer, fluorescent protein, KillerRed, mutagenesis, hypsochromic shift, optogenetics

Funding: this work would not have been published without the generous support and the strict publication requirements of the Russian Foundation for Basic Research grant 18-04-01173. KSS is supported by the president fellowship 075-15-2019-411. Experiments were partially carried out using the equipment provided by the Institute of Bioorganic Chemistry of the Russian Academy of Sciences Core Facility (CKP IBCH; supported by Russian Ministry of Education and Science Grant RFMEFI62117X0018)

Acknowledgements: we thank to the Center for Precision Genome Editing and Genetic. Technologies for Biomedicine (Moscow) for the genetic research methods. Author contribution: Sarkisyan KS, Gorbachev DA — conceived and planned the project, performed the experiments, analysed data and prepared the manuscript. Compliance with ethical standards: no animal or human subjects were used in this study.

$\triangle$ Correspondence should be addressed: Karen S. Sarkisyan

Miklukho-Maklaya, 16/10, of. 34/632, Moscow, 117997; karen.s.sarkisyan@gmail.com

Received: 08.12.2019 Accepted: 18.12.2019 Published online: 20.12.2019

DOI: $10.24075 /$ brsmu.2019.084

\section{МУТАНТ ФОТОТОКСИЧНОГО БЕЛКА KILLERRED, НЕ ФОРМИРУЮЩИЙ DSRED-ПОДОБНОГО ХРОМОФОРА}

\section{Д. А. Горбачев, К. С. Саркисян $ه$}

Институт биоорганической химии имени М. М. Шемякина и Ю. А. Овчинникова, Москва, Россия

Генетически кодируемые фотосенсибилизаторы на основе флуоресцентных белков способны производить активные формы кислорода при облучении светом, и потому их широко используют в качестве оптогенетических инструментов. Разработанные на сегодняшний день фотосенсибилизаторы с зеленой флуоресценцией обладают неоптимальными свойствами. Целью настоящей работы был поиск новых вариантов флуоресцентных белков с эффективным созреванием хромофора и высокой фототоксичностью. С помощью случайного мутагенеза фототоксичного флуоресцентного белка KillerRed и направленной эволюции в E. coli получен белок с хромофором на основе тирозина, флуоресцирующий в зеленой области спектра. Новый белок, несущий мутации I64L, D114G и T115S, не формирует DsRed-подобного хромофора и может быть использован как базовый генотип для разработки новых спектрально отличных от KillerRed генетически кодируемых фотосенсибилизаторов.

Ключевые слова: фотосенсибилизатор, флуоресцентный белок, KillerRed, мутагенез, гипсохромный сдвиг, оптогенетика

Финансирование: работа не была бы опубликована без поддержки грантом РФФИ 18-04-01173 и грантом Президента РФ 075-15-2019-411. Исследования частично выполнены на оборудовании ЦКП ИБХ РАН.

Благодарности: авторы признательны Центру высокоточного редактирования и генетических технологий для биомедицины (Москва) за помощь в методах исследования.

Информация о вкладе авторов: К. С. Саркисян, Д. А. Горбачев - планирование проекта, проведение экспериментов, анализ данных, подготовка рукописи статьи. Вклад авторов в работу равнозначен на всех этапах.

Соблюдение этических стандартов: в настоящей работе не проводили экспериментов на животных или людях, результаты не представляют интерес для создания технологий двойного назначения.

$\triangle$ Для корреспонденции: Карен Сергеевич Саркисян

ул. Миклухо-Маклая, 16/10, оф. 34/632, г. Москва, 117997; karen.s.sarkisyan@gmail.com

Статья получена: 08.12.2019 Статья принята к печати: 18.12.2019 Опубликована онлайн: 20.12.2019

DOI: $10.24075 /$ vrgmu.2019.084

Fluorescent proteins are widely used as genetically encodable tags for optical labeling of living systems [1]. Their chromophores are located inside the protein structure and are protected from the surrounding solvent; therefore, most of the existing fluorescent proteins are passive reporter molecules: irradiation with light does not significantly affect cells expressing these markers.

At the same time, a unique family of genetically encoded photosensitizers has been developed based on the fluorescent protein anm2CP. Upon light illumination, members of the family produce reactive oxygen species that can damage the cell [2]. Structural studies of these proteins have identified a water-filled channel that connects the chromophore to the solvent. This structural feature of phototoxic fluorescent proteins is thought to be responsible for the efficient diffusion of reactive oxygen species into the environment $[3,4]$.

KillerRed was the first protein engineered to produce reactive oxygen species demonstrating phototoxicity levels exceeding other fluorescent proteins more than thousand-fold [2]. Depending on the cellular localization and the excitation light dose, reactive oxygen species generated by KillerRed can lead to various physiological consequences - from inactivation of fusion proteins [2], to cell division arrest [5, 6] or cellular death through necrosis or apoptosis $[2,7]$. Due to these capabilities, KillerRed is used as an optogenetic tool in cell biology to inactivate proteins with light, to study intracellular oxidative stress or to ablate specific cell populations. KillerRed 
has also been used as a photosensitizer for treatment of tumors in model systems [7-9].

Other genetically encoded photosensitizers have been created based on KillerRed, including SuperNova, a monomeric KillerRed variant with similar spectral characteristics [10], as well as orange fluorescent protein KillerOrange [11] and green fluorescent protein SuperNova Green [12]. Besides that, nonfluorescent protein-based photosensitizers miniSOG, Pp2FbFP and others that generate singlet oxygen have been developed $[13,14]$.

None of the existing photosensitizers with green fluorescence can be universally used in relevant applications. Some proteins demonstrate incomplete or slow chromophore maturation rate; others may not generate the type of reactive oxygen species suitable for a particular application, or their phototoxicity may depend on the availability of external chromophore [15]. In this work, we aimed to find a mutant version of KillerRed that did not form a DsRed-like "red" chromophore and, therefore, could serve as a basis for the development of the new generation of efficient photosensitizers with green fluorescence.

\section{METHODS}

\section{DNA amplification and analysis of amplification products}

DNA amplification was performed using the Encyclo PCR Kit (Evrogen; Russia) on a PTC-200 Thermal Cycler (MJ Research; USA). The analysis of amplification products was carried out in 1-2\% agarose gel. Ethidium bromide was used at a concentration of $0.5 \mu \mathrm{g} / \mathrm{ml}$.

\section{Generation of the mutant library for directed evolution}

Mutagenesis was performed by error-prone PCR. We added manganese ions and a skewed ratio of nucleotide triphosphates (50x mix: 0.2 MM dGTP, 0.2 MM dATP, 1 MM dCTP, 1 MM dTTP) into the PCR reaction mixture leading errors in Taq-polymerasebased DNA amplification. The average mutation rate was 8 nucleotide substitutions per 1000 amplified nucleotides after 25 cycles of PCR.

For electroporation, the ligation mixture was purified on Cleanup Mini DNA purification columns (Evrogen; Russia). $40 \mu \mathrm{l}$ of electrocompetent cells were thawed on ice, and up to $5 \mu$ of purified ligation mixture was added to thawed cells. Cells were then transferred into a pre-cooled electroporation cuvette (Bio-Rad; USA) and electroporated on the MicroPulser device (Bio-Rad; USA). Immediately after electroporation, $3 \mathrm{ml}$ of SOB medium was added to the cuvette, and the bacterial suspension was transferred into $1.5 \mathrm{ml}$ plastic tubes. The tubes were incubated for one hour in an incubator at $37{ }^{\circ} \mathrm{C}$ and then plated on LB agar. The plates were incubated at $37^{\circ} \mathrm{C}$ for 18 hours. The average density of $E$. coli colonies was 5,000 per plate and the total diversity of genotypes in the library was estimated to be around 100,000 clones. The number of fluorescent colonies was $22 \%$.

\section{Expression and purification of recombinant proteins}

E. coli $\mathrm{XL1}$ Blue was grown in $800 \mathrm{ml}$ flasks in LB medium with ampicillin $(100 \mathrm{mg} / \mathrm{ml})$, induced with isopropyl- $\beta$-D-1thiogalactopyranoside to the final concentration $0.5 \mathrm{mM}$ and incubated for 3 hours. All further operations were performed on ice. The culture was centrifuged, the supernatant was discarded, the pellet was resuspended in $4 \mathrm{ml}$ of phosphate buffer ( $\mathrm{pH}$ 7.4), the suspension was lysed in Sonics Vibra Cell sonicator (Sonics \& Materials; USA) and centrifuged again. The supernatant was transferred into a new tube with $400 \mu \mathrm{l}$ of Talon metal-affinity resin (Clontech; USA), equilibrated with phosphate buffer. The tube was placed in a shaker for one hour at $200 \mathrm{rpm}$ at room temperature. Then, the resin with the protein was washed several times with phosphate buffer and eluted with phosphate buffer containing imidazole (250 mM).

\section{RESULTS}

We relied on random mutagenesis to find KillerRed mutant with green fluorescence. The mutant library was cloned into pQE-30 vector, transformed into $E$. coli cells and grown on agar plates without induction. We visually screened bacterial colonies exposed by $400 \mathrm{~nm}$ and $480 \mathrm{~nm}$ light to identify mutants with significant green fluorescence and identified the KillerRed I64L D114G/T115S mutant (see Table, the numbering of positions in the protein is indicated according to the established notation so that the chromophore-forming residues are in positions 65-67 [1]). This mutant had very dim fluorescence in the red part of the spectrum while being noticeably fluorescent in green under when illuminated with $480 \mathrm{~nm}$ light. Observed spectral properties indicated that the protein formed the "classical" GFP-like chromophore instead of the DsRed-like chromophore found in the parental KillerRed.

Since proteins with GFP-like chromophores and DsRedlike chromophores have specific absorption spectra that are easily distinguishable from each other, we isolated and purified KillerRed protein and it's mutant KillerRed I64L/D114G/T115S (Fig. 1). The absorption spectrum of purified KillerRed I64L D114G T115S was significantly different from the absorption spectrum of KillerRed and had a pick with the maximum at $514 \mathrm{~nm}$ and a blue-shifted shoulder characteristic of GFP-like chromophores.

\section{DISCUSSION}

The lack of absorbance at 550-600 nm in KillerRed 164L/ D114G/T115S indicated that introduced mutations almost entirely prevented formation of DsRed-like chromophore. The peak with a maximum at $514 \mathrm{~nm}$ and a characteristic shoulder at $480-485 \mathrm{~nm}$ suggested that chromophore catalysis stopped at a "classical" GFP-like chromophore [1].

Mutations found in the KillerRed variant we identified are interesting in the context of existing literature on fluorescent proteins mutagenesis. In particular, mutations at position 64

Table. Amino acid sequences of proteins described in this study. Chromophore-forming residues are highlighted in purple, positions containing mutations are highlighted in orange

\begin{tabular}{l|l}
\hline $\begin{array}{l}\text { Amino acid sequence of KillerRed I64L D114G T115S } \\
\text { (identified in this study) }\end{array}$ & $\begin{array}{l}\text { MRGSHHHHHHGSEGGPALFQSDMTFKIFIDGEVNGQKFTIVADGSSKFPHGDFNVHAVCETGK } \\
\text { LPMSWKPICHLLQYGEPFFARYPDGISHFAQECFPEGLSIDRTVRFENDGTMTSHHTYELDGSC } \\
\text { VVRITVNCDGFQPDGPIMRDQLVDILPNETHMFPHGPNAVRQLAFIGFTTADGGLMMGHFDS } \\
\text { KMTFNGSRAIEIPGPHFVTIITKQMRDTSDKRDHVCQREVAYAHSVPRITSAIGSDED }\end{array}$ \\
\hline Amino acid sequence of KillerRed & MRGSHHHHHHGSGGPALFQSDMTFKIFIDGEVNGQKFTIVADGSSKFPHGDFNVHAVCETGK \\
& LPMSWKPICHLIQYGEPFFARYPDGISHFAQECFPEGLSIDRTVRFENDGTMTSHHTYELDDTCV \\
VSRITVNCDGFQPDGPIMRDQLVDILPNETHMFPHGPNAVRQLAFIGFTTADGGLMMGHFDSK & MTFNGSRAIEIPGPHFVTIITKQMRDTSDKRDHVCQREVAYAHSVPRITSAIGSDED \\
\hline
\end{tabular}




\section{ORIGINAL RESEARCH I GENETICS}

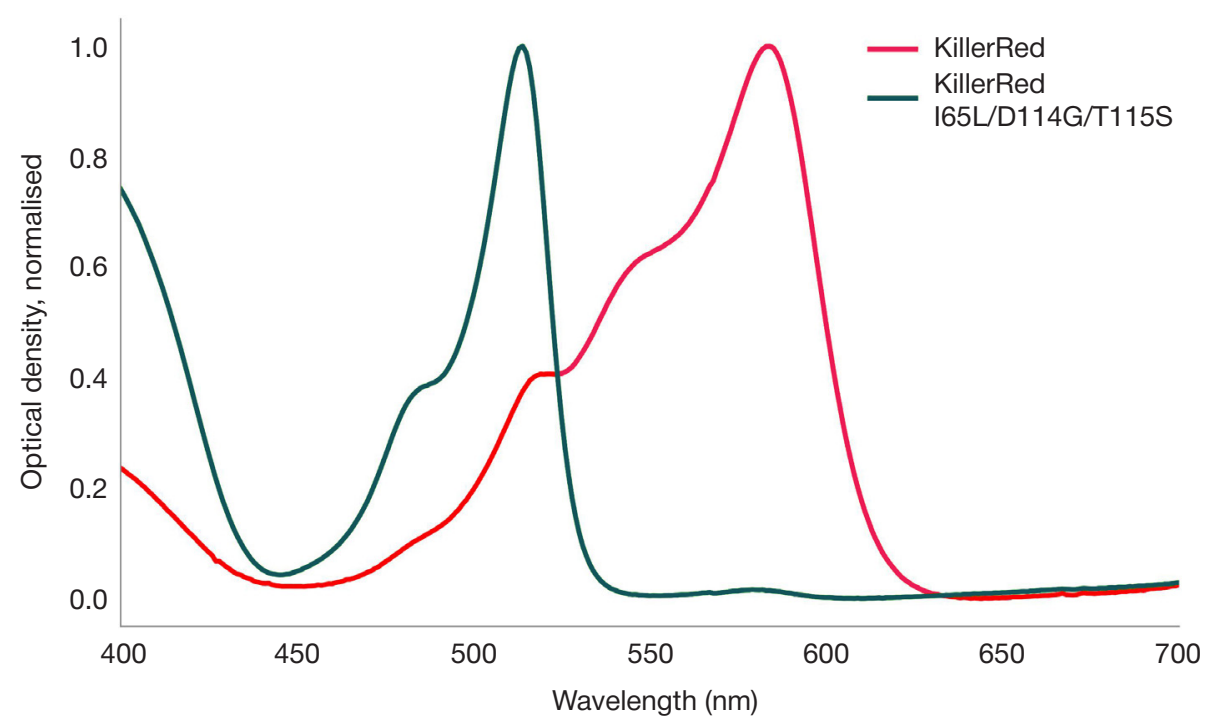

Fig. 1. Absorption spectra of purified proteins KillerRed and KillerRed I64L/D114G/T115S

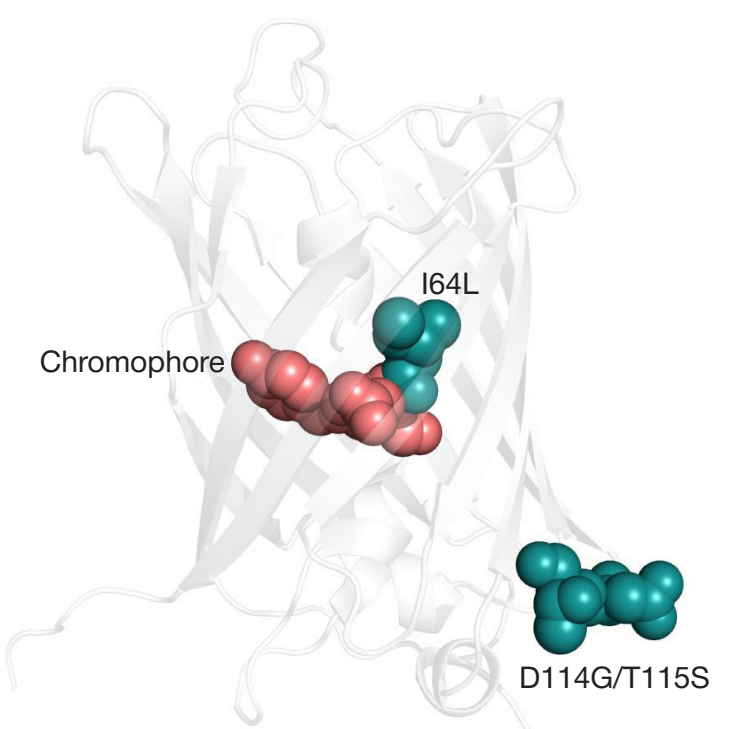

Fig. 2. Location of the chromophore and mutations I64L, D114G and T115S in the structure of KillerRed.

were previously described as affecting chromophore maturation: for instance, in Aequorea victoria GFP, the F64L mutation improves maturation of the chromophore when expressed at $37^{\circ} \mathrm{C}$ [1], while in the chromoprotein from Acropora millepora the S64C mutation changes the color of the protein [16]. Mutations D114G and T115S are located in the neighboring positions on the loop connecting the beta-strands 5 and 6 (Fig. 2) and may contribute to the adaptation of the beta-barrel to the replacement of isoleucine with leucine at position 64.

\section{References}

1. Chudakov DM, Matz MV, Lukyanov S, Lukyanov KA. Fluorescent proteins and their applications in imaging living cells and tissues. Physiol Rev. 2010; (9)0: 1103-63. DOI:10.1152/ physrev.00038.2009/=

2. Bulina ME, Chudakov DM, Britanova OV, Yanushevich YG, Staroverov DB, Chepurnykh TV, et al. A genetically encoded photosensitizer. Nat Biotechnol. 2006; (24): 95-9. DOl:10.1038/ nbt1175.

3. Pletneva NV, Pletnev VZ, Sarkisyan KS, Gorbachev DA, Egorov ES, Mishin AS, et al. Crystal Structure of Phototoxic Orange

\section{CONCLUSION}

The KillerRed variant described in this work is a promising template for further directed evolution to create a new generation of genetically encodable photosensitizers with green fluorescence. Unlike other KillerRed spectral variants developed to date, the KillerRed I64L/D114G/T115S mutant forms a tyrosine-based chromophore and exhibits fluorescence in the green region of the spectrum.
Fluorescent Proteins with a Tryptophan-Based Chromophore. PLoS One. 2015; (10): e0145740. DOl:10.1371/journal.pone.0145740.

4. Pletnev S, Gurskaya NG, Pletneva NV, Lukyanov KA, Chudakov DM, Martynov VI, et al. Structural basis for phototoxicity of the genetically encoded photosensitizer KillerRed. J Biol Chem. 2009; (284): 32028-39. DOI:10.1074/jbc.M109.054973.

5. Serebrovskaya EO, Gorodnicheva TV, Ermakova GV, Solovieva EA, Sharonov GV, Zagaynova EV, et al. Light-induced blockage of cell division with a chromatin-targeted phototoxic fluorescent protein. Biochem J. 2011; (435): 65-71. DOI:10.1042/BJ20101217. 
6. Lan L, Nakajima S, Wei L, Sun L, Hsieh C-L, Sobol RW, et al. Novel method for site-specific induction of oxidative DNA damage reveals differences in recruitment of repair proteins to heterochromatin and euchromatin. Nucleic Acids Res. 2014; (42): 2330-45. DOI:10.1093/nar/gkt1233.

7. Shirmanova MV, Serebrovskaya EO, Lukyanov KA, Snopova LB, Sirotkina MA, Prodanetz NN, et al. Phototoxic effects of fluorescent protein KillerRed on tumor cells in mice. J Biophotonics. 2013; (6): 283-90. DOl:10.1002/jbio.201200056.

8. Kuznetsova DS, Shirmanova MV, Dudenkova W, Subochev PV, Turchin IV, Zagaynova EV, et al. Photobleaching and phototoxicity of KillerRed in tumor spheroids induced by continuous wave and pulsed laser illumination. J Biophotonics. 2015; 9999. DOI:10.1002/jbio.201400130.

9. Yan L, Kanada M, Zhang J, Okazaki S, Terakawa S. Photodynamic Treatment of Tumor with Bacteria Expressing KillerRed. PLoS One. 2015; (10): e0131518. DOI:10.1371/journal.pone.0131518.

10. Takemoto K, Matsuda T, Sakai N, Fu D, Noda M, Uchiyama S, et al. SuperNova, a monomeric photosensitizing fluorescent protein for chromophore-assisted light inactivation. Sci Rep. 2013; (3): 2629. DOI:10.1038/srep02629.

11. Sarkisyan KS, Zlobovskaya OA, Gorbachev DA, Bozhanova NG, Sharonov GV, Staroverov DB, et al. KillerOrange, a Genetically

\section{Литература}

1. Chudakov DM, Matz MV, Lukyanov S, Lukyanov KA. Fluorescent proteins and their applications in imaging living cells and tissues. Physiol Rev. 2010; (9)0: 1103-63. DOl:10.1152/ physrev.00038.2009/=.

2. Bulina ME, Chudakov DM, Britanova OV, Yanushevich YG, Staroverov DB, Chepurnykh TV, et al. A genetically encoded photosensitizer. Nat Biotechnol. 2006; (24): 95-9. DOl:10.1038/ nbt1175.

3. Pletneva NV, Pletnev VZ, Sarkisyan KS, Gorbachev DA, Egorov ES, Mishin AS, et al. Crystal Structure of Phototoxic Orange Fluorescent Proteins with a Tryptophan-Based Chromophore. PLOS One. 2015; (10): e0145740. DOI:10.1371/journal.pone.0145740.

4. Pletnev S, Gurskaya NG, Pletneva NV, Lukyanov KA, Chudakov DM, Martynov VI, et al. Structural basis for phototoxicity of the genetically encoded photosensitizer KillerRed. J Biol Chem. 2009; (284): 32028-39. DOl:10.1074/jbc.M109.054973.

5. Serebrovskaya EO, Gorodnicheva TV, Ermakova GV, Solovieva EA, Sharonov GV, Zagaynova EV, et al. Light-induced blockage of cell division with a chromatin-targeted phototoxic fluorescent protein. Biochem J. 2011; (435): 65-71. DOI:10.1042/BJ20101217.

6. Lan L, Nakajima S, Wei L, Sun L, Hsieh C-L, Sobol RW, et al. Novel method for site-specific induction of oxidative DNA damage reveals differences in recruitment of repair proteins to heterochromatin and euchromatin. Nucleic Acids Res. 2014; (42): 2330-45. DOl:10.1093/nar/gkt1233.

7. Shirmanova MV, Serebrovskaya EO, Lukyanov KA, Snopova LB, Sirotkina MA, Prodanetz NN, et al. Phototoxic effects of fluorescent protein KillerRed on tumor cells in mice. J Biophotonics. 2013; (6): 283-90. DOI:10.1002/jbio.201200056.

8. Kuznetsova DS, Shirmanova MV, Dudenkova W, Subochev PV, Turchin IV, Zagaynova EV, et al. Photobleaching and phototoxicity of KillerRed in tumor spheroids induced by continuous wave and pulsed laser illumination. J Biophotonics. 2015; 9999.
Encoded Photosensitizer Activated by Blue and Green Light. PLoS One. 2015; (10): e0145287. DOI:10.1371/journal.pone.0145287.

12. Riani YD, Matsuda T, Takemoto K, Nagai T. Green monomeric photosensitizing fluorescent protein for photo-inducible protein inactivation and cell ablation. BMC Biol. 2018; (16): 50 DOI:10.1186/s12915-018-0514-7

13. Shu X, Lev-Ram V, Deerinck TJ, Qi Y, Ramko EB, Davidson MW, et al. A genetically encoded tag for correlated light and electron microscopy of intact cells, tissues, and organisms. PLoS Biol. 2011; (9): e1001041. DOl:10.1371/journal.pbio.1001041.

14. Torra J, Burgos-Caminal A, Endres S, Wingen M, Drepper T, Gensch T, et al. Singlet oxygen photosensitisation by the fluorescent protein Pp2FbFP L30M, a novel derivative of Pseudomonas putida flavin-binding Pp2FbFP. Photochem Photobiol Sci. 2015; (14): 280-7. DOI:10.1039/c4pp00338a.

15. Acharya A, Bogdanov AM, Grigorenko BL, Bravaya KB, Nemukhin AV, Lukyanov KA, et al. Photoinduced Chemistry in Fluorescent Proteins: Curse or Blessing? Chem Rev. 2017; (117): 758-95. DOl:10.1021/acs.chemrev.6b00238.

16. Alieva NO, Konzen KA, Field SF, Meleshkevitch EA, Hunt ME, Beltran-Ramirez V, et al. Diversity and evolution of coral fluorescent proteins. PLoS One. 2008; (3): e2680. DOI:10.1371/journal. pone.0002680

DOI:10.1002/jbio.201400130.

9. Yan L, Kanada M, Zhang J, Okazaki S, Terakawa S. Photodynamic Treatment of Tumor with Bacteria Expressing KillerRed. PLoS One. 2015; (10): e0131518. DOI:10.1371/journal.pone.0131518

10. Takemoto K, Matsuda T, Sakai N, Fu D, Noda M, Uchiyama S, et al. SuperNova, a monomeric photosensitizing fluorescent protein for chromophore-assisted light inactivation. Sci Rep. 2013; (3): 2629. DOI:10.1038/srep02629

11. Sarkisyan KS, Zlobovskaya OA, Gorbachev DA, Bozhanova NG, Sharonov GV, Staroverov DB, et al. KillerOrange, a Genetically Encoded Photosensitizer Activated by Blue and Green Light. PLoS One. 2015; (10): e0145287. DOI:10.1371/journal.pone.0145287.

12. Riani YD, Matsuda T, Takemoto K, Nagai T. Green monomeric photosensitizing fluorescent protein for photo-inducible protein inactivation and cell ablation. BMC Biol. 2018; (16): 50 DOI:10.1186/s12915-018-0514-7.

13. Shu X, Lev-Ram V, Deerinck TJ, Qi Y, Ramko EB, Davidson MW, et al. A genetically encoded tag for correlated light and electron microscopy of intact cells, tissues, and organisms. PLoS Biol. 2011; (9): e1001041. DOl:10.1371/journal.pbio.1001041.

14. Torra J, Burgos-Caminal A, Endres S, Wingen M, Drepper T, Gensch T, et al. Singlet oxygen photosensitisation by the fluorescent protein Pp2FbFP L30M, a novel derivative of Pseudomonas putida flavin-binding Pp2FbFP. Photochem Photobiol Sci. 2015; (14): 280-7. DOI:10.1039/c4pp00338a.

15. Acharya A, Bogdanov AM, Grigorenko BL, Bravaya KB, Nemukhin AV, Lukyanov KA, et al. Photoinduced Chemistry in Fluorescent Proteins: Curse or Blessing? Chem Rev. 2017; (117): 758-95. DOI:10.1021/acs.chemrev.6b00238.

16. Alieva NO, Konzen KA, Field SF, Meleshkevitch EA, Hunt ME, Beltran-Ramirez $\mathrm{V}$, et al. Diversity and evolution of coral fluorescent proteins. PLoS One. 2008; (3): e2680. DOl:10.1371/journal. pone.0002680 